\title{
OPTIMASI PENJADWALAN PERKULIAHAN MENGGUNAKAN METODE HARMONY SEARCH
}

\author{
Oleh: ${ }^{1}$ Abd.Rahman, ${ }^{2}$ Eko Mulyanto Yuniarno, ${ }^{2}$ I Ketut Eddy \\ Purnama \\ ${ }^{1}$ Mahasiswa Pascasarjana Jurusan Teknik Elektro ITS Surabaya, ${ }^{2,3}$ Dosen Jurusan \\ Teknik Elektro ITS Surabaya \\ E-mail: ${ }^{1}$ rahman13@mhs.ee.its.ac.id
}

\begin{abstract}
Abstrak
Penjadwalan perkuliahan pada suatu perguruan tinggi adalah kegiatan rutin tiap semester dan merupakan suatu proses untuk menerapkan event yang berisi komponen mata kuliah dan kelas pada time slot yang berisi komponen waktu dan ruang. Permasalahan yang sering terjadi dalam kegiatan penjadwalan adalah terjadinya pertentangan antara jadwal yang satu dengan yang lain. Salah satu metode untuk menyelesaikan permasalahan tersebut ialah dengan menggunakan bantuan kecerdasan buatan atau Artificial Intelligence (Al). Salah satu metode dalam Al yang dianggap dapat memberikan solusi atas permasalahan penjadwalan ialah Harmony Search. Harmony Search merupakan suatu wilayah ilmu komputer yang mendasarkan algoritmanya pada musik. Algoritma Harmony Search menganalogikan musik dengan segala perangkatnya dengan permasalahan optimasi. Misalnya, setiap alat musik berkaitan dengan variabel keputusan, nada musik berkaitan dengan nilai variabel, harmoni berhubungan dengan vektor solusi. Seperti seorang musisi yang memainkan musik tertentu, berimprovisasi memainkan nada secara random atau berdasarkan pengalaman untuk menemukan harmoni yang indah, variabel dalam Harmony Search mempunyai nilai random atau nilai yang didapat dari iterasi (memory) dalam usaha mendapatkan solusi optimal. Dengan menerapkan algoritma Harmony Search dalam penyusunan jadwal perkuliahan, maka diharapkan dapat tercipta suatu susunan jadwal perkuliahan yang optimal.
\end{abstract}

Kata kunci: Optimasi, Penjadwalan, Artificial Intelligence, Harmony Search.

\section{Pendahuluan}

Pengaturan jadwal perkuliahan di suatu perguruan tinggi merupakan suatu hal yang sangat penting, karena pelaksanaan kegiatan perkuliahan melibatkan banyak aspek yang saling berkaitan satu sama lain dan masing-masing memiliki prioritas yang berbeda-beda. Aspek-aspek yang menjadi bahan pertimbangan dalam penjadwalan antara lain adalah jumlah mahasiswa, dosen, waktu, ruangan serta persyaratan-persyaratan lainnya.

Proses kegiatan belajar mengajar pada sebuah perguruan tinggi tidak dapat lepas dari faktor penjadwalan perkuliahan. Semakin bagus sistem penjadwalan 
perkuliahan, maka akan semakin teratur dan optimal pula proses belajar mengajar pada perguruan tinggi tersebut. Namun pada kenyataannya untuk menyusun sebuah penjadwalan perkuliahan, bukanlah sebuah pekerjaan yang tergolong mudah. Ada banyak kendala yang bisa menyulitkan pembuatan jadwal.

Faktor lain yang turut mempersulit penjadwalan perkuliahan ialah terdapat keterbatasan dosen pengampuh sementara mata kuliah yang diajarkan cukup banyak, ruang kelas yang terbatas dan pertambahan kelas baru seiring dengan pertambahan jumlah mahasiswa setiap tahunnya. Karena prosesnya masih serba manual dan diperparah lagi dengan tingkat ketelitian yang kurang konsisten sehingga menyebabkan jadwal yang dihasilkan menjadi kurang sempurna. Hal ini disebabkan karena masih adanya pelanggaran-pelanggaran terhadap persyaratan yang ada, misalnya jadwal yang bentrok ruang kelasnya atau jam mengajarnya, dosen yang mengajar berhalangan hadir dan lain-lain.

Sistem penjadwalan kuliah di beberapa institusi perguruan tinggi sampai saat ini masih dilakukan secara manual, yaitu dengan pencarian blok-blok atau kolom-kolom mana saja yang masih kosong, kemudian menempatkan jadwal pada blok atau kolom tersebut. Jadwal yang dihasilkan dengan cara seperti ini memerlukan waktu yang cukup lama dan cenderung mengabaikan berbagai aspek tersebut. Sehingga jadwal kuliah dan ujian yang sudah dibuat seringkali perlu dilakukan perbaikan lagi. Oleh karena itu perlu dikembangkan suatu sistem penjadwalan kuliah dan ujian yang dapat mengakomodasi berbagai aspek yang menjadi pertimbangan diatas.

Sebelumnya telah pernah dilakukan penelitian tentang penjadwalan perkuliahan antara lain seperti yang dilakukan oleh Heni Rachmawati [11]. Penelitian dilakukan dengan menggunakan teknik pewarnaan graph dengan algoritma koloni lebah. Begitupun dengan penelitian tentang penerapan algoritma harmony search, telah pernah dilakukan oleh Indra Aulia [13]. Penelitian dilakukan dengan menerapkan algoritma harmony search dalam penyelesaian masalah penjadwalan flowshop.

Pada artikel ini dilakukan penelitian yang hasil akhirnya nanti dapat digunakan sebagai solusi untuk mengatasi 
kesulitan dalam hal pembuatan jadwal perkuliahan. Dalam penelitian ini, digunakan algoritma Harmony Search sebagai metode optimasi penjadwalan

Harmony Search termasuk pendekatan metaheuristik yang mendasarkan algoritmanya pada musik. Ada analogi antara musik dengan segala perangkatnya dengan permasalahn optimasi. Misalnya, setiap alat musik berkaitan dengan variabel keputusan, nada msuik berkaitan dengan nilai variabel, harmoni berhubungan dengan vektor solusi. Seperti seorang musisi yang memainkan musik tertentu, berimprovisasi memainkan nada secara random atau berdasarkan pengalaman untuk menemukan harmoni yang indah, variabel dalam Harmony Search mempunyai nilai random atau nilai yang didapat dari iterasi (memory) dalam usaha mendapatkan solusi optimal.. Hal inilah yang kemudian diibaratkan sebagai suatu solusi optimum dari sebuah permasalahan optimasi dalam hal ini penyusunan jadwal perkuliahan[1]. Dengan menggunakan algoritma Harmony Search diharapkan dapat diperoleh jadwal yang optimal yaitu kondisi kombinasi terbaik dalam penjadwalan tersebut.

Tujuan dari penelitian ini adalah untuk menghasilkan suatu sistem penjadwalan perkuliahan yang optimal dengan menggunakan algoritma Harmony Search sebagai teknik optimasinya.

\section{Analisis dan Pembahasan}

1. Algoritma Harmony Search

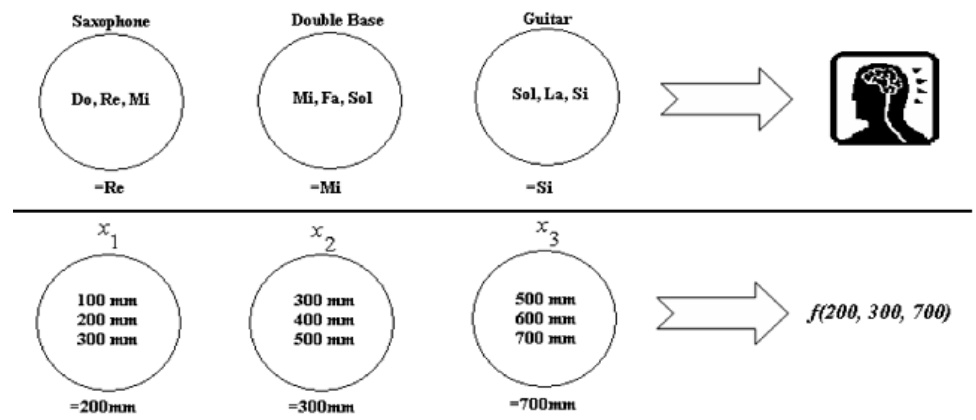

Gambar 1. Struktur Algoritma Harmony Search [13].

Pada Gambar 1, setiap pemain musik (saxophonist, 
double bassist dan guitarist) merepresentasikan suatu decision variable ( $\mathrm{x} 1, \mathrm{x} 2$, dan $\mathrm{x} 3$ ). Kumpulan bunyi yang dihasilkan oleh setiap instrumen musik (saxophone $=\{$ Do, $\mathrm{Re}, \mathrm{Mi}\}$; double bass $=\{\mathrm{Mi}, \mathrm{Fa}$, Sol $\}$; guitar $=\{\mathrm{Sol}, \mathrm{La}, \mathrm{Si}\})$ menyatakan rentang nilai variabel $(x 1=\{100,200,300\}$; $x 2$ $=\{300,400,500\} ; \times 3=\{500,600,700\})$. Sebagai contoh, misalnya saxophonist mengeluarkan bunyi $R e$, double bassist membunyikan Fa dan guitarist mengeluarkan bunyi La, maka ketiganya membangun suatu harmoni baru ( Re, $\mathrm{Fa}$, La ). Jika harmoni ini lebih indah dibandingkan harmoni saat ini, maka harmoni baru ini dipertahankan. Harmoni yang diperoleh tersebut dalam dunia optimasi disebut dengan solusi yang direpresentasikan dalam bentuk dimensi vektor solusi.

Berdasarkan konsep diatas, algoritma Harmony Search terdiri atas lima tahapan, yakni :

1) Inisialisasi paramater Harmony Search

Minimasi (atau maksimasi) $f(x)$

dengan $x_{i} \in X_{i}, i=1,2, \ldots N$

dimana :

$f(x)$ adalah suatu fungsi objektif

$x_{i}$ adalah variabel keputusan ke $\mathrm{i}$

$X_{i}$ adalah himpunan variabel keputusan

$N$ merupakan jumlah variabel keputusan

Parameter-parameter yang dibutuhkan adalah sebagai berikut :

a) Harmony Memory Size (HMS) adalah banyaknya vektor solusi yang terbentuk

b) Harmony Memory Consideration Rate (HMCR) bernilai 0 $\leq \mathrm{HMCR} \leq 1$. Umumnya berkisar antara 0,7 sampai 0,99

c) Pitch Adjustment Rate (PAR) bernilai $0 \leq$ PAR $\leq 1$. Umumnya berkisar antara 0,1 sampai 0,5

d) Kriteria berhenti, adalah banyaknya iterasi untuk melakukan improvisasi.

2) Inisialisasi Harmony Memory (HM)

Persamaan 1 merepresentasikan inisialisasi HM yang didapatkan dengan membangkitkan variabel keputusan $x_{i}$ ecara acak sehingga membentuk vektor solusi $X_{i}$.Kemudian 
51 | al-Khwarizmi, Volume II, Edisi 2, Oktober 2014, Hal. 47 - 58

hitung nilai fungsi objektif $f(x)$ masing-masing vektor solusi.

$$
H M=\left[\begin{array}{llcccc}
x_{1}^{1} & x_{1}^{2} & x_{1}^{3} & \ldots & x_{1 N-1}^{1} & x_{N}^{1} \\
x_{1}^{2} & x_{2}^{2} & x_{3}^{2} & \ldots & x_{N-1}^{2} & x_{p}^{2} \\
\vdots & \cdots & \ldots & \ldots & \ldots & \ldots \\
x_{1}^{H M S-1} & x_{2}^{H M S-1} & x_{3}^{H M S-1} & \ldots & x_{p-1}^{H M S-1} & x_{N}^{H M S-1} \\
x_{1}^{H M S} & x_{2}^{H M S} & x_{3}^{H M S} & \ldots & x_{N-1}^{H M S} & x_{N}^{H M S}
\end{array}\right]
$$

dimana masing-masing vektor solusi (tiap baris) akan dievaluasi nilai fungsinya

$$
f(x)=\left[\begin{array}{c}
f\left(x^{1}\right) \\
f\left(x^{2}\right) \\
\vdots \\
f\left(x^{H M S-1}\right) \\
f\left(x^{H M S}\right)
\end{array}\right]
$$

Dalam penelitian ini, anggota dari himpunan variabel keputusan merupakan representasi dari banyaknya mata kuliah yang akan diproses. Sebagai contoh, jika terdapat 6 mata kuliah yang akan diproses pada 5 slot waktu, maka himpunan variabel keputusan yang terbentuk adalah $\mathrm{X}=$ $\{1,2,3,4,5,6\}$. Sehingga inisialisasi $H M$ yang mungkin terbentuk adalah sebagai berikut :

$$
H M=\left[\begin{array}{lllll}
2 & 3 & 1 & 4 & 5 \\
1 & 4 & 2 & 3 & 5 \\
4 & 1 & 3 & 2 & 5 \\
3 & 1 & 4 & 5 & 2
\end{array}\right]
$$

Setelah didapat vektor solusi sebanyak HMS yakni banyaknya baris dari HM, maka selanjutnya hitunglah nilai fungsi objektif masing-masing vektor tersebut.

3) Improvisasi harmoni baru Improvisasi harmoni dilakukan dengan pembangkitan harmoni baru $x_{i}$ sehingga membentuk vektor solusi baru $x^{\prime}=\left(x_{1}^{\prime}, x_{2}^{\prime}, \ldots, x_{N}^{\prime}\right)$. Pembangkitan harmoni baru tersebut dilakukan dengan dua aturan yaitu :

a. Harmony memory consideration 
Pada tahap ini nilai variabel keputusan $x$ 'dipilih secara acak dari variabel-variabel mana saja yang tersimpan dalam HM $\left(x_{i}^{1}, x_{i}^{2}, \ldots, x_{i}^{H M S}\right)$ dengan probabilitas $x^{\prime}$.

Pembangkitan variabel keputusan yang tidak berada pada HM, maka akan dipilih secara acak dari himpunan variabel $x$ 'dengan probabilitas $1-H M C R$. Pembangkitan variabel keputusan baru pada tahap ini seperti pada Persamaan 3

$$
x_{1}^{\prime}=\left\{\begin{array}{cl}
\left.\left.x_{1}^{\prime} \in x_{i}^{1}, x_{i}^{2}, \ldots, x_{i}^{H M S}\right\}\right) & H M C R \\
x_{1}^{\prime} \in X_{i} & H M C R-1
\end{array} .\right.
$$

b. Pitch adjusment

Tahap ini merupakan tahap penyesuaian variabel keputusan baru $x_{i}$ yang dihasilkan pada tahap harmony memory consideration. Variabel keputusan tersebut akan disesuaikan dengan variabel-variabel tetangganya dengan probabilitas $H M C R \times P A R$. Variabel keputusan $x_{i}$ yang dihasilkan oleh harmony memory consideration dipertahankan dengan probabilitas $H M C R x(1-P A R)$

4) Update HM

Nilai fungsi objektif dari vektor solusi baru nilainya buruk daripada vektor-vektor yang ada pada HM, maka vektorvektor solusi dalam HM tetap dipertahankan.

5) Kriteria berhenti

Kriteria berhenti menentukan banyaknya proses pembangkitan solusi baru dan memperbarui HM. Apabila kriteria berhenti terpenuhi maka proses iterasi akan berhenti.

Dari keseluruhan tahapan, dapat dituangkan kedalam diagram alir seperti pada Gambar 2. 
53 | al-Khwarizmi, Volume II, Edisi 2, Oktober 2014, Hal. 47 - 58

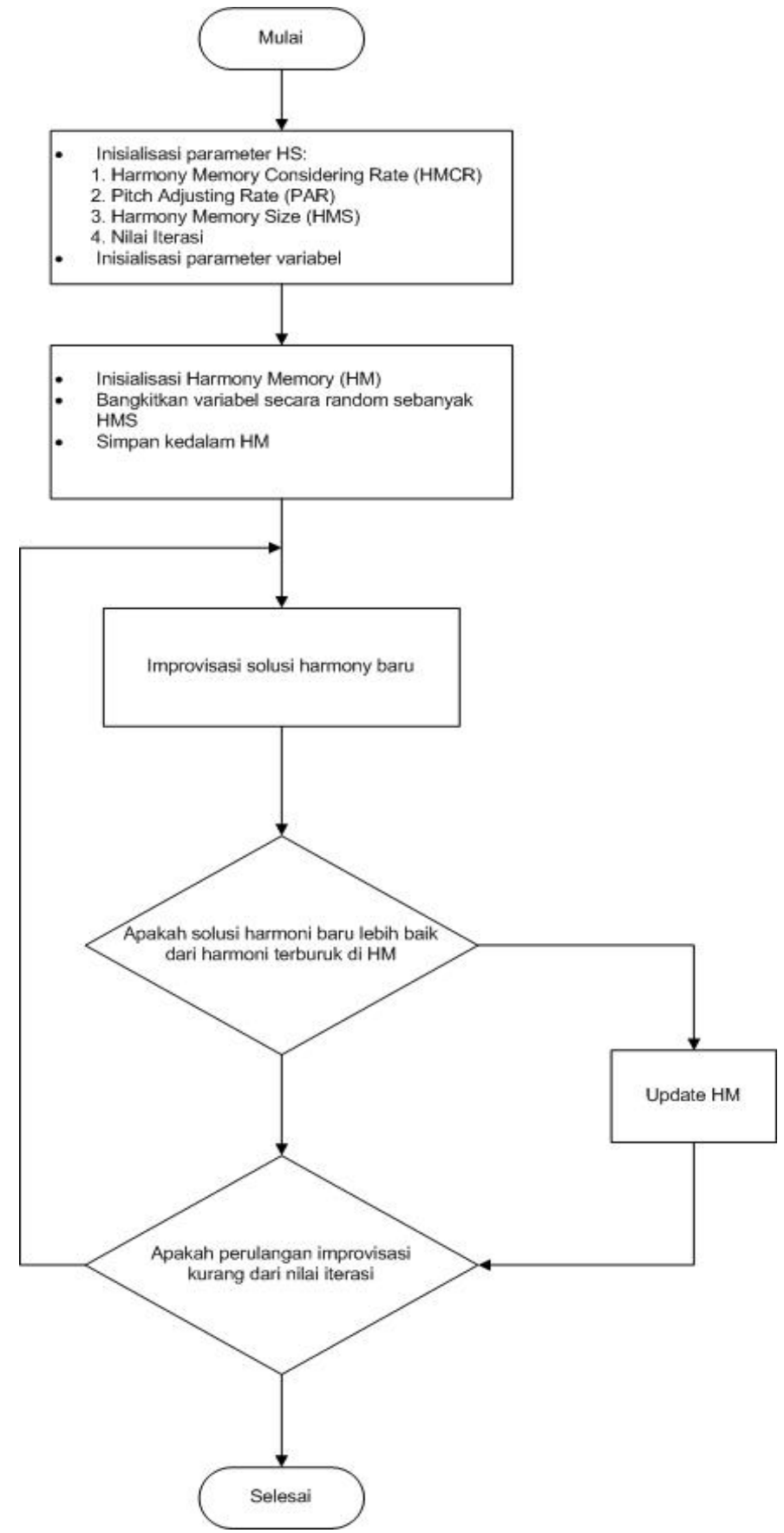

Gambar 2. Diagram Alir Algoritma Harmony Search 


\section{Pengujian}

Untuk menguji unjuk kerja sistem, uji coba dilakukan dengan melihat hasil dari beberapa kriteria sebagai berikut :

1) Persentase perkuliahan yang berhasil dijadwalkan.

2) Persentase pelanggaran terhadap hard constraints.

3) Persentase pelanggaran terhadap soft constraints.

4) Waktu komputasi yang digunakan untuk menghasilkan solusi.

Data yang digunakan adalah data perkuliahan semester genap tahun akademik 2013/2014 pada Jurusan Tarbiyah STAIN Palopo. Data tersebut diperoleh dari Sub Bagian Akademik STAIN Palopo. Terdiri atas 332 perkuliahan, 129 mata kuliah, dosen pengampu sebanyak 109 orang. Adapun jumlah ruang sebanyak 17 ruang. Slot waktu yang tersedia ialah 8 slot perhari yang dibagi atas dua sesi, yaitu sesi pagi dan sesi siang. Satu sks menggunakan satu slot waktu yang lamanya 45 menit, dengan hari perkuliahan mulai hari senin sampai dengan hari sabtu.

Faktor yang sangat menentukan dalam penjadwalan ialah batasan (constraints), terbagi atas constraints yaitu batasan yang tidak boleh dilanggar dan soft constraints yaitu batasan yang boleh dilanggar tetapi sedapat mungkin dihindari (diminimalisir). Dalam penelitian ini yang menjadi hard contraints adalah sebagai berikut :

1) Tidak ada dosen yang mengajar lebih dari satu mata kuliah pada waktu yang bersamaan.

2) Tidak ada dosen yang berada pada lebih dari satu ruangan pada waktu yang bersamaan.

3) Sebuah ruangan hanya dapat digunakan oleh satu kelas pada satu waktu tertentu.

4) Kapasitas ruangan harus sama dengan atau lebih besar dari kapasitas kelas yang akan diadakan.

Sedangkan yang ditetapkan sebagai soft constraints ialah sebagai berikut :

1) Diusahakan untuk mengakomodir permintaan dosen untuk tidak mengajar pada waktu-waktu tertentu.

2) Diusahakan seorang dosen tidak mengajar lebih dari dua kali dalam sehari

Tabel 1. Parameter Pengujian

\begin{tabular}{|c|c|c|}
\hline No & Parameter & Nilai Parameter \\
\hline 1 & Jumlah perkuliahan & 332 \\
\hline
\end{tabular}


55 | al-Khwarizmi, Volume II, Edisi 2, Oktober 2014, Hal. 47 - 58

\begin{tabular}{|c|l|c|}
\hline 2 & Jumlah ruang & 17 \\
\hline 3 & Jumlah dosen & 109 \\
\hline 4 & Jumlah slot waktu & 48 \\
\hline 5 & HMCR & 0,98 \\
\hline 6 & PAR & 0,02 \\
\hline 7 & HMS & 48 \\
\hline 8 & $\mathrm{NI}$ & 100 \\
\hline
\end{tabular}

\section{Hasil Pengujian}

Pengujian dilakukan pada komputer laptop dengan spesifikasi prosesor Intel Core i5 2,30 GHz dan RAM sebesar $4 \mathrm{~GB}$. Menggunakan bantuan program aplikasi yang dibangun dengan menggunakan bahasa pemrograman Java dengan environment Netbean 7.5. Sedangkan untuk pengelolaan data base menggunakan MySql ver. 5.0.65.

Proses penjadwalan dilakukan oleh program aplikasi tersebut dengan mengkalkulasi data-data masukan seperti data dosen, data mata kuliah, dan data kelas. Data tersebut disimpan dalam masing-masing tabel data base. Kemudian oleh program aplikasi diambil dan dimasukkan kedalam matriks dengan dimensi kolom mewakili ruang dan baris mewakili time slot. Matriks tersebut kemudian dihitung dengan menggunakan prinsip-prinsip algoritma harmony search seperti yang telah diuraikan di bagian sebelumnya. Tujuan dari perhitungan yang dilakukan ialah untuk menghasilkan susunan vektor matriks dengan nilai fungsi objektif yang seminimal mungkin atau dengan kata lain untuk menghasilkan sebuah vektor solusi yang paling feasible.

Setelah dilakukan beberapa kali percobaan dengan beberapa macam kombinasi nilai paremeter (HMCR, PAR, HMS, NI) akhirnya solusi terbaik didapatkan seperti diuraikan pada Tabel 2.

Tabel 2. Hasil Pengujian

\begin{tabular}{|c|l|c|}
\hline No & \multicolumn{1}{|c|}{ Parameter } & Ket. \\
\hline 1 & $\begin{array}{l}\text { Persentase perkuliahan yang berhasil } \\
\text { dijadwalkan }\end{array}$ & $100 \%$ \\
\hline 2 & Persentase pelanggaran hard constraints & $0 \%$ \\
\hline 3 & Persentase pelanggaran soft constraints & $0 \%$ \\
\hline 4 & Waktu komputasi & 53 detik \\
\hline
\end{tabular}

Dari hasil pengujian seperti yang diuraikan pada Tabel 
2, dari jumlah perkuliahan sebanyak 332 berhasil dijadwalkan seluruhnya atau dengan kata lain tidak ada perkuliahan yang tidak berhasil dijadwalkan. Dari empat hard constraints yang ditetapkan ternyata tidak ada yang dilanggar, begitupun dengan dua soft constraints tidak ada yang dilanggar. Jumlah waktu yang dibutuhkan untuk membangun sebuah solusi ialah sebesar 53 detik.

\section{Penutup}

1. Kesimpulan

1) Metode Harmony Search dapat digunakan untuk penyelesaian masalah penjadwalan perkuliahan.

2) Metode Harmony Search berhasil memberikan solusi optimum tanpa ada satupun pelanggaran baik hard constraints maupun soft constraints.

2. Saran

1) Penambahan constraints lain, sehingga dapat menghasilkan sistem yang lebih optimal.

2) Mencoba metode optimasi yang lain, yang nantinya dapat dibandingkan dengan penelitian ini. 
57 | al-Khwarizmi, Volume II, Edisi 2, Oktober 2014, Hal. 47 - 58

\section{Daftar Pustaka}

[1] Budi Santosa, Paul Willy. 2011. Metoda Heuristik, Konsep dan Implementasi. Guna Widya. Surabaya.

[2] Suyanto. 2007. Artificial Intelligence; Searching, Reasoning, Planning and Learning. Informatika. Bandung.

[3] Anita Desiani, Muhammad Arhami. 2006. Konsep Kecerdasan Buatan. Andi Offset. Yogyakarta.

[4] Zong Woo Geem, Joong Hoo Kim, G.V. Loganathan 2001. A New Heuristic Optimization Algorithm: Harmony Search. in Simulation vol. 76 no. 2 hal. 60-68 Auburn.

[5] M. Mahdavi, M. Fesanghary. E. Damangir. 2007. An. Improved Harmony Search Algorithm for Solving Optimization Problems. in Applied Mathematics and Computation vol. 188. hal. 1567-1579.

[6] Teddy. 2009. Penyelesaian Penjadwalan Kuliah Sebagai Constraint Satisfaction Problem dengan Genetic Algorithm. Tesis Magister. Fasilkom UI. Jakarta

[7] Sri Kusumadewi, Hari Purnomo. 2005. Penyelesaian Masalah Optimasi dengan Teknik-teknik Heuristik. Graha Ilmu. Yogyakarta.

[8] Thomas Sri Widodo. 2011. Komputasi Evolusioner. Graha Ilmu. Yogyakarta.

[9] Jaco Fourie, Richard Gree, Zong Woo Geem. 2013. Generalised Adaptive Harmony Search: A Comparative Analysis of Modern Harmony Search, in Journal of Applied Mathematics Vol. 2013 ed. Xin-She Yang. New York.

[10] Komang Setemen. 2008. Kombinasi Algoritma Genetika dan Tabu Search dalalm Penyusunan Jadwal Kuliah. ITS. Surabaya.

[11] Heni Rachmawati. 2012. Analisis Penyelesaian Masalah Penjadwalan Kuliah Menggunakan Pewarnaan Graph oleh Algoritma Koloni Lebah dengan Parameter Soft Contsraints Prioritas Dosen. ITS. Surabaya.

[12] Dwi Ana Ratna Wati, Yuli Agusti Rochman. 2008. Model Penjadwalan Matakuliah Secara Otomatis Berbasis Algoritma Particle Swarm Optimization (PSO) UII. Yogyakarta. 
[13] Indra Aulia, Erna Budhiarti Nababan, M. Anggia Muchtar. 2012. Penerapan Harmony Search Algorithm dalam Permasalahan Penjadwalan Flow Shop. Jurnal Dunia Teknologi Informasi vol. 1 hal. 1-7. Medan.

[14] Niko Sutiono, Ngarap Imanuel Malik, Rojali. 2012. Automatisasi Timetabling Asisten Pengajar pada Software Laboratory Center menggunakan Harmony Search. Binus University. Jakarta. 